UDC 616-097:616-056.3:57.083.322

A. Ye. Bogomolov

National Pirogov Memorial Medical University, Vinnytsya

\title{
Usage of medical thermography to evaluate the results of skin prick testing of patients with allergic rhinitis
}

Key words: skin prick testing, allergy, western-blotting, bilastine, thermography.

For allergists from all around the world, the fact of the increase in the prevalence of allergic diseases, both among children and adults, has long been obvious. The detection, diagnosis and treatment of this pathology are increasingly being pursued by doctors of related specialties - family medicine, pulmonologists, ENT and others. However, the main difference of the allergist from the above specialties has always been, is and will be the use of specific methods of diagnosis and treatment. Despite the development of serological and component-resolved methods for diagnosing of sensitization, the most important role of the primary test of the first level still belong to skin prick testing (SPT) $[1,2]$. Obviously, SPT is not only a minimally invasive, fast, specific test, but also the most accessible to the population of our country at a cost. The main difficulties in using this method are due to two reasons - the assessment should be carried out by a specially trained specialists and the sensitivity of the test due to a number of factors may sometimes not be very high.

Among laboratory serological tests in vitro, western-blotting is one of the most common and available. The obvious advantages of this investigation are low invasiveness, independence from drug history, the possibility of use in pediatric practice and objectivity. However, the specificity of the test and expensiveness sometimes limit its scope. In the practice of the clinician, sometimes there are cases of dissonance of the results of examinations by these methods, which is associated with a number of factors [3, 4].

Thermography has found wide application in various areas of human life - construction, veterinary medicine, and medicine. Application of the method in medical practice

(C) A. Ye. Bogomolov, 2018

www.search.crossref.org

DOI: 10.31655/2307-3373-2018-4-25-28 is especially valuable in sports medicine, early diagnosis of breast cancer, and problems with the thyroid gland. Using thermography can help optimize SPT assessment, increasing its objectivity [5].

The aim of our investigation was to study aspects of the use of medical thermography to evaluate the results of skin testing with allergen solutions in patients with allergic rhinitis in comparison with the western-blot method.

\section{Materials and methods}

50 patients ( 30 females and 20 males) aged 18 to 45 years were examined in accordance with the guidelines of the ethics committee of the National Pirogov memorial medical university, all were beyond the acute period. The inclusion criteria were allergic rhinitis diagnosis (both intermittent and persistent) with proven sensitivity to domestic or pollen allergens. SPT was carried out according to the classical testing procedure in accordance with regulatory documents with commercial extracts of allergens (Immunolog, Vinnitsa, Ukraine). For the test, a positive (histamine dihydrochloride solution $0.01 \%$ - Solutio histamini dihydrochloridi $0.01 \%$ pro diagnostica cutanea morborum allergicorum) and negative (sodium chloride, disodium phosphate dodecahydrate (sodium phosphate dibasic), potassium dihydrogen phosphate (potassium phosphate monosubent phenol, tween 80, water for injection) controls (Immunolog, Vinnitsa, Ukraine) were used. The following allergen extracts were used - Mix allergen pollen No. 1 (birch, alder, oak, hazelnut), Mix allergen pollen No. 2 (mud, whitney, thinnest, bonfire, pineapple), Mix - allergen pollen No. 3 (pyrite, rye, timothy), Mix - allergen pollen No. 4 (ambrosia, rape, sunflower), Mix - allergen domestic No. 5 (home dust with 
Dermatophagoides farinae, Dermatophagoides pteronyssinus, Acarus siro and feathers of pillows) with subsequent testing with a separate allergen extracts in case of a positive result. SPT results were assessed in 15 min visually using a ruler in $\mathrm{mm}$ and were classified according to the existing scale as negative, doubtful, weak $(+)$, strong $(++)$ and very strong $(++)$.

Immediately after a visual assessment, an instrumental assessment was carried out using a thermograph with image fixation in the memory of the device for subsequent processing. Several rules were necessary for thermographic evaluation - the patient had to be indoors for $30 \mathrm{~min}$ utes before the test to stabilize the skin temperature, which was checked before SPT using a single thermogram of the forearms. For thermography, a ULIRVision TI-120 camera (Zhejiang ULIRvision Technology Co., Hangzhou, China) was used, certified by a range of temperatures and sensitivity for medical use in Ukraine. A standard medical interview and the qualification of patient were performed during an earlier visit, and then, $15 \mathrm{~mL}$ of blood for the sIgE-test was collected.

Western blot testing for specific IgE-levels was performed using RIDA qLine test systems (R-Biopharm AG, Darmstadt, Germany). The sIgE-concentration was converted to a nominal scale (grades) according to the following rules: <0.35 IU mL-1-level 0 (negative), (0.36-0.69) IU mL-1-level 1 (boundary levels), (0.7-3.49) IU mL-1level 2 (slightly elevated), (3.50-17.4) IU mL-1-level 3 (moderately elevated), (17.5-49, 9) IU mL-1-level 4 (high levels), (50-100) IU mL-1-level 5 (very high levels) and $>100$ IU mL-1-level 6 (extremely high levels).

After the initial intake and testing procedure, the antihistamine drug bilastine (NIXAR, Berlin-Chemie Menarini Group, Berlin, Germany) was prescribed in the average recommended daily dosage $20 \mathrm{mg}$ one tablet per day and initial recommendations for elimination measures were given. Three days later, all patients underwent SPT and its thermographic evaluations to determine the degree of suppression of the skin reaction with an antihistamine.

For all comparisons between the panels Bland-Altman plot was made to evaluate correlation and systematic errors of tests. Statistical analysis was done using Statistica base 12.0 (Dell Software Company; Aliso Viejo, CA, USA).

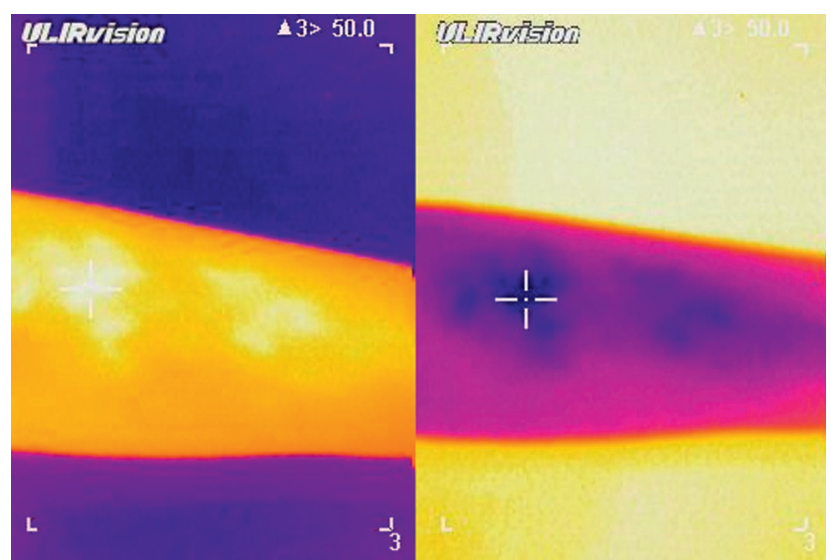

Fig. 1. Example of the thermogram of the left forearm (left) as well as the result of image filter after skin prick test (right)

\section{Results and discussion}

The maximum number of allergen extracts tested for a single patient was 8 , while minimum number was 5 . The sensitization was quantified using the above-described categorized scale. The mildews and molds fungi were excluded from further analysis due to too low number of positive western-blot results ( 3 cases) and temporary unavailable commercial allergen extracts for SPT. The total number of allergic tests, both positive and negative, among all of 50 patients was 352 .

An example of a thermogram of the left forearm after testing (left) and applying computer filters (right) for accurate calibration of the instrument measurements is shown in Fig. 1.

According to the results of skin prick testing monosensitization was found in 12 patients ( $26.6 \%$ of cases). The most frequently observed sensitization was to pollen allergens (rye 34 patients (37.7\% of cases), birch - 32 patients $(35.5 \%$ of cases), alder - 25 patients (26.6\% of cases)) and household mites allergens (D. pteronissynus - 33 patients $(37.7 \%$ of cases) and D. farinae - 30 patients (33.3\% of cases)). The results of skin testing of patients are shown in Fig. 2.

By the analysis of results comparison between the visual and thermographic measurement of wheals after prick-tests we found high correlation coefficient of determination $(\mathrm{r}=0.9)$, however the difference between the sizes of a papule in average was $1.5 \mathrm{~mm}$. Ten tests were interpreted visually as negative and thermographically as doubtful. However, in the analysis of results coincidence of the visual analysis by allergists and a thermographic picture made only $70 \%$ of cases of the carried-out tests. Absolute matching of clinical and thermal image results was observed only for the negative ones.

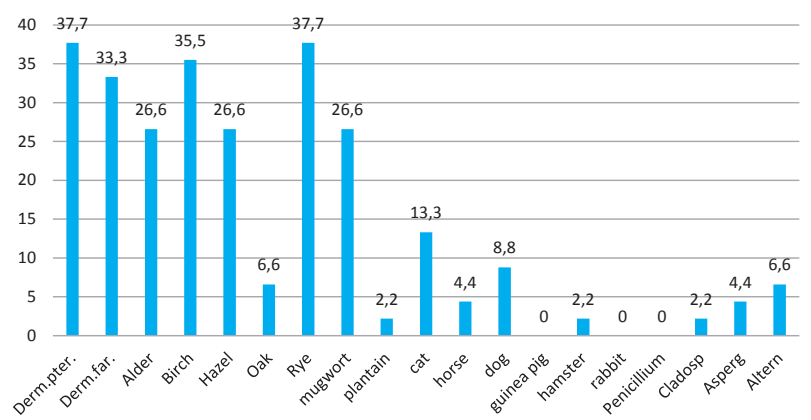

Fig. 2. Sensitization frequency by skin prick testing, \%.

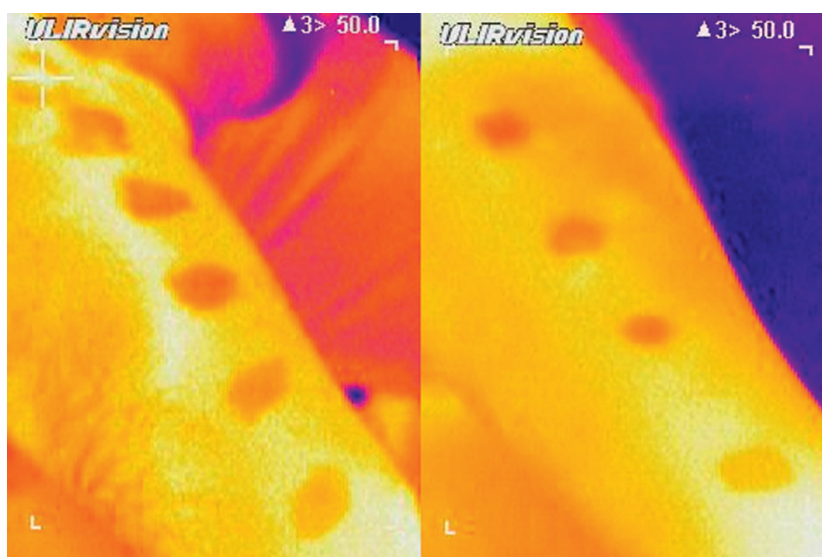

Fig. 3. Example of the thermogram of the right forearm (left) as well as the result on the left forearm (right) after72 hours of bilastine taking. 
All classified allergic reactions were compared with each other. The gamma correlation coefficients between all considered methods are shown in the table.

Given the general agreement between diagnostic methods, the best agreement was observed between the TH and sIgE results (correlation coefficient- $r=0.91$ ), while TH-SPT was the most divergent pair of $r=0.81$. In the case of particular allergens, the highest correlation was 0.99 , and the smallest value was 0.76 . This allows us to believe with confidence that the most objective was the SPT assessment by the thermography method, which also shows the difference in the results of visual and instrumental measurement of papules.

The second part of our study was to verify the results of SPT 72 hours after the start of taking the H1-histamine blocker drug (bilastine). An example of a thermogram of a patient's forearms with SPT performed before and 72 hours after the start of administration is seen in Fig. 3.

As a result of the analysis and subsequent statistical processing, it was found that, on average, the papule diameter of the positive test upon re-examination decreased by $57.2 \%$ (95\% CI: $0.51 ; 0.59)$. At the same time, the absolute majority of patients $(87.2 \%$ (95\% CI: 0.83 ; 0.91)) did not completely eliminate the positive samples. The complete disappearance of samples in 95\% (95\% CI: 0.91; 0.97) cases occurred in patients with weak $(« 1+»)$ severity of samples before taking bilastin. Thus, bilastin, as a typical representative of fast-acting antihistamines, inhibits the classic allergic reaction during skin testing. However, in patients who have only a few doses of an antihistamine drug in history prior to the onset of SPT, the severity of skin tests is often reduced, rather than their complete disappearance.

\section{Conclusions}

Thus, medical thermography can be used in the routine practice of the allergist to objectify the results of the
Table. Correlation between thermographic (TH) and visual (SPT) interpretation of skin tests versus slgE-determination by western-blot.

\begin{tabular}{|l|c|c|c|}
\hline \multirow{2}{*}{ Allergen } & \multicolumn{3}{|c|}{ Correlation coefficient } \\
\cline { 2 - 4 } & $\begin{array}{c}\text { TH versus } \\
\text { SPT }\end{array}$ & $\begin{array}{c}\text { TH versus } \\
\text { slgE }\end{array}$ & $\begin{array}{c}\text { SPT versus } \\
\text { slgE }\end{array}$ \\
\hline Total & $0.81^{*}$ & $0.91^{*}$ & $0.87^{*}$ \\
\hline Mix 1 & 0.86 & $0.86^{*}$ & $0.72^{\times}$ \\
\hline Mix 2 & 0.81 & 0.92 & $0.82^{\times}$ \\
\hline Mix 3 & $0.75^{\times}$ & 0.85 & 0.84 \\
\hline Mix 4 & 0.87 & 0.91 & $0.91^{*}$ \\
\hline D. pteronyssinus & $0.83^{*}$ & 0.88 & 0.92 \\
\hline D. farinae & 0.94 & 0.92 & $0.91^{*}$ \\
\hline Rye & 0.83 & 0.91 & 0.99 \\
\hline Birch & 0.73 & $0.76^{\times}$ & 0.87 \\
\hline Alder & 0.91 & 0.91 & 0.89 \\
\hline
\end{tabular}

Notes: ${ }^{*}$ - statistically valuable difference $(p<0,05)$ between results.

evaluation of skin testing using the prick test method. In the future, this may allow improving the quality of diagnosis of sensitization in patients with allergic diseases.

However, our studies on the analysis of the results of repeated skin tests in patients after taking an antihistamine can be recommended in case of a history of only a few days of intake, try starting with testing with $0.01 \%$ histamine hydrochloride solution (positive control). In the case of a positive test result, it is possible to perform all subsequent tests with the attention that the results can be reduced. Further research in this area is needed for a more accurate action algorithm.

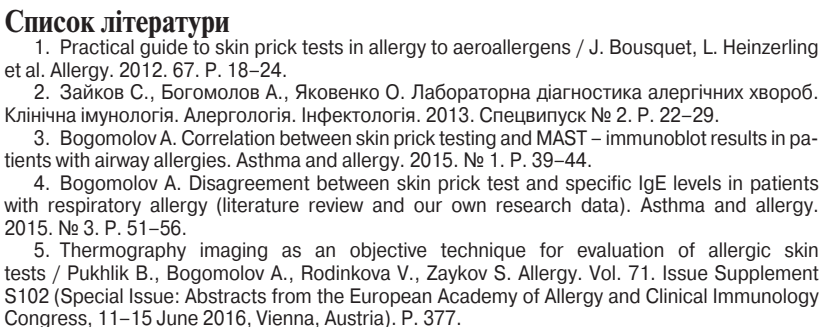

1. Practical guide to skin prick tests in allergy to aeroallergens / J. Bousquet, L. Heinzerling tal. Allergy. 2012. 67. P. 18-24

2. Зайков С., Богомолов А., Яковенко О. Лабораторна діагностика алергічних хвороб. Клінічна імунологія. Алергологія. Інфектологія. 2013. Спецвипуск № 2. Р. $22-29$.

3. Bogomolov A. Correlation between skin prick testing and MAST - immunoblot results in paents with airway allergies. Asthma and allergy. 2015. № 1. P. 39-44.

4. Bogomolov A. Disagreement between skin prick test and specific IgE levels in patients with respiratory allergy (literature review and our own research data). Asthma and allergy. 015. № 3. P. 51-56.

5. Thermography imaging as an objective technique for evaluation of allergic skin ests / Pukhlik B., Bogomolov A., Rodinkova V., Zaykov S. Allergy. Vol. 71. Issue Supplement 102 (Special Issue: Abstracts from the European Academy of Allergy and Clinical Immunology S102(Sp, 11-15 June 2016, Vienna, Austria). P. 377.

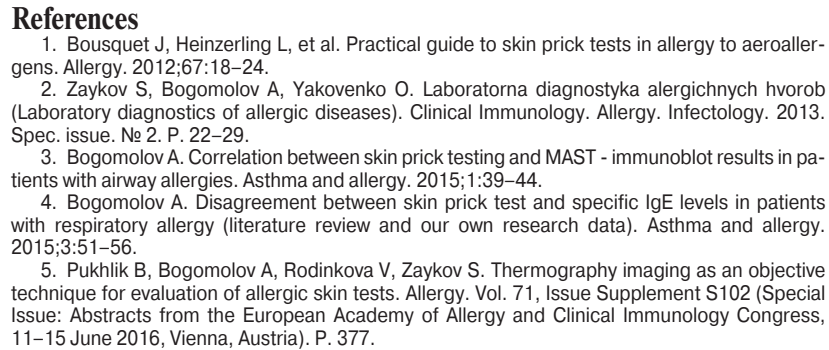

1. Bousquet $\mathrm{J}$, Heinzerling $\mathrm{L}$, et al. Practical guide to skin prick tests in allergy to aeroallergens. Allergy. 2012;67:18-24.

2. Zaykov S, Bogomolov A, Yakovenko O. Laboratorna diagnostyka alergichnych hvorob (Laboratory diagnostics of allergic diseases). Clinical Immunology. Allergy. Infectology. 2013. Spec. issue. № 2. P. 22-29

3. Bogomolov A. Correlation between skin prick testing and MAST - immunoblot results in paents with airway allergies. Asthma and allergy. 2015;1:39-44.

4. Bogomolov A. Disagreement between skin prick test and specific IgE levels in patients with respiratory allergy (literature review and our own research data). Asthma and allergy. 2015;3:51-56.

5. Pukhlik B, Bogomolov A, Rodinkova V, Zaykov S. Thermography imaging as an objective technique for evaluation of allergic skin tests. Allergy. Vol. 71, Issue Supplement S102 (Specia Issue: Abstracts from the European Academy of Allergy and Clinical Immunology Congress,
11-15 June 2016, Vienna, Austria). P. 377.

\section{ИСПОЛЬЗОВАНИЕ МЕДИЦИНСКОЙ ТЕРМОГРАФИИ ДЛЯ ОЦЕНКИ РЕЗУЛЬТАТОВ ТЕСТИРОВАНИЯ МЕТОДОМ ПРИК-ТЕСТА У ПАЦИЕНТОВ С АЛЛЕРГИЧЕСКИМ РИНИТОМ}

\section{А.Е. Богомолов}

\section{Резюме}

Целью исследования было изучение аспектов использования медицинской термографии для оценки результатов кожного тестирования растворами аллергенов у пациентов с аллергическим ринитом по сравнению с иммуноблоттингом.

Материалы и методы. 50 пациентов (30 женщин и 20 мужчин) в возрасте от 18 до 45 лет были обследованы в соответствии с руководящими принципами комитета по этике Винницкого национального медицинского университета, все они были в фазе ремиссии. Критерии включения - диагноз аллергического ринита (как интермиттирующий, так и персистирующий) с доказанной 
чувствительностью к аллергенам домашней или пыльцевой группы. Прик-тесты проводили в соответствии с классической процедурой тестирования по нормативным документам с коммерческими экстрактами аллергенов.

Для термографии использовалась камера ULIRVision TI-120, сертифицированная по диапазону температур и чувствительности для медицинского использования в Украине. Иммуноблоттинг-тестирование для количественных уровней IgE проводили с использованием тест-систем RIDA qLine. После первоначальной процедуры приема и тестирования назначали антигистаминный препарат биластин. Через три дня все пациенты прошли еще раз кожное тестирование и его термографическую оценку, чтобы определить степень ингибирования кожной реакции антигистаминным препаратом.

Результаты и обсуждение. В целом, между методами определения сенсибилизации наблюдалась согласованность результатов, при этом наилучшая корреляция наблюдалась между результатами термографии и $\operatorname{sg} E$ (коэффициент корреляции $\mathrm{r}=0,91$ ), тогда как термография-визуальная оценка прик-тестов была самой расходящейся парой $(\mathrm{r}=0,81)$. Наибольшая корреляция результатов тестирования аллергенами составляла 0,99 , а наименьшее значение $-0,76$.

В среднем, диаметр папулы положительного теста при повторном осмотре уменьшился на 57,2\% (95\% ДИ: 0,51, 0,59). В то же время у абсолютного большинства пациентов $(87,2 \%$ (95\% ДИ: 0,$83 ; 0,91))$ не полностью исчезли положительные пробы. Полное исчезновение проб в 95\% случаев (95\% ДИ: 0,91; 0,97) наблюдалось у пациентов со слабой («1+») выраженностью образцов до приема биластина.

Ключевые слова: прик-тест, аллергия, иммуноблоттинг, биластин, термография.

Научно-практический журнал «Астма и аллергия», 2018, № 4

А. Е. Богомолов, канд. мед. наук, доцент Винницкий национальный медицинский университет им. Н.И. Пирогова

ул. Пирогова, 56, г. Винница, Украина, 21000; тел.: +38(097) 066-35-55; e-mail: art.bogomolov@gmail.com

\section{ВИКОРИСТАННЯ МЕДИЧНОЇ ТЕРМОГРАФІЇ ДЛЯ ОЦІНКИ РЕЗУЛЬТАТІВ ТЕСТУВАННЯ МЕТОДОМ ПРИК-ТЕСТУ У ПАЦІЄНТІВ 3 АЛЕРГІЧНИМ РИНІТОМ}

\section{А.Є. Богомолов}

Резюме

Метою дослідження було вивчення аспектів використання медичної термографії для оцінки результатів шкірного тестування розчинами алергенів у пацієнтів з алергічним ринітом у порівнянні з імуноблотингом.

Матеріали та методи. 50 пацієнтів (30 жінок і 20 чоловіків) віком від 18 до 45 років були обстежені відповідно до основних принципів комітету з етики Вінницького національного медичного університету, всі вони були в фазі ремісії. Критерії включення - діагноз алергічного риніту (як інтермітуючий, так і персистуючий) з доведеною чутливістю до алергенів домашньої або пилкової групи. Прик-тести проводили відповідно до класичної процедури тестування за нормативними документами 3 комерційними екстрактами алергенів.

Для термографії використовувалася камера ULIRVision TI-120, сертифікована за діапазоном температур і чутливості для медичного використання в Україні. Імуноблотинг-тестування для кількісних рівнів IgE проводили з використанням тест-систем RIDA qLine. Після початкової процедури прийому і тестування призначали антигістамінний препарат біластин. Через три дні всі пацієнти пройшли ще раз шкірне тестування і його термографічну оцінку, щоб визначити ступінь інгібування шкірної реакції антигістамінним препаратом.

Результати та обговорення. Загалом між методами визначення сенсибілізації спостерігалася узгодженість результатів, при цьому найкраща узгодженість спостерігалася між результатами термографії і sIgE (коефіцієнт кореляції r = 0,91), тоді як термографія візуальна оцінка прик-тестів була найбільш розбіжною парою ( $\mathrm{r}=0,81)$. Найбільша кореляція результатів тестування алергенами становила 0,99, а найменше значення - 0,76.

В середньому діаметр папули позитивного тесту при повторному огляді зменшився на 57,2\% (95\% ДІ: 0,51, 0,59). Водночас у абсолютної більшості пацієнтів (87,2\% (95\% ДІ: 0,83; 0,91)) не в повному обсязі зникли позитивні проби. Повне зникнення проб в 95\% випадків (95\% ДІ: 0,91; 0,97) спостерігалося у пацієнтів зі слабкою («1+») вираженістю проб до прийому біластину.

Ключові слова: прик-тест, алергія, імуноблотинг, біластин, термографія.

Науково-практичний журнал «Астма та алергія», 2018, № 4

А.С. Богомолов, канд. мед. наук, доцент Вінницький національний медичний університет ім. М.I. Пирогова

вул. Пирогова, 56, м. Вінниця, Україна, 21000; тел.: +38 (097) 066-35-55; e-mail: art.bogomolov@gmail.com

\section{А.С. Богомолов:}

ORCID iD

orcid.org/ 0000-0002-5336-4858 